\title{
PENGENALAN BIBLIOMETRIC MAPPING SEBAGAI BENTUK PENGEMBANGAN LAYANAN RESEARCH SUPPORT SERVICES PERGURUAN TINGGI
}

\author{
Lis Setyowati \\ Fakultas Teknik Universitas Diponegoro \\ lis@ft.undip.ac.id
}

\begin{abstract}
ABSTRAK
Para peneliti dituntut untuk mengikuti perkembangan di bidang mereka masing-masing. Hal ini akan sulit dilakukan bila mereka tidak memiliki pengetahuan dan keterampilan yang mendukung hal ini. Pengetahuan dan keterampilan seperti ini dapat diperoleh melalui pelatihan. Pelatihan seperti ini bisa menjadi kesempatan emas yang bisa dimanfaatkan oleh perpustakaan. Perpustakaan perguruan tinggi bisa mengembangkan layanan yang mendukung riset dengan menyediakan layanan bibliometric mapping dan mengajarkan penggunaan perangkat lunak bibliometric mapping. Dengan menggunakan pendekatan kajian pustaka, tulisan ini bertujuan untuk memberikan gambaran peluang untuk menawarkan layanan yang berkaitan dengan bibliometri di perpustakaan. Tulisan ini mengeksplorasi bibliometric mapping sebagai metode yang dapat digunakan untuk mendapatkan visualisasi publikasi di suatu bidang ilmu. Dengan memanfaatkan data bibliografis dari pangkalan data seperti SCOPUS, Web of Science atau PubMed, seseorang bisa mendapatkan gambaran tentang tokoh yang mempunyai peran menonjol dan juga topik-topik popular di bidangbidang tertentu. Meskipun bibliometric mapping berpotensi untuk menjadi perpanjangan bentuk dari jasa rujukan di perpustakaan, namun hal ini masih belum dianggap penting. Untuk mengenalkan metode ini kepada para peneliti, maka perpustakaan bisa menawarkan pelatihan "Literature Review" dan mengenalkan software yang berkaitan.
\end{abstract}

Kata kunci: perpustakaan perguruan tinggi; research support services; analisa bibliometri; literature review; bibliometric mapping

\section{PENDAHULUAN}

Penelitian merupakan hal penting bagi perguruan tinggi karena merupakan bagian dari Tri Dharma. Pemerintah, melalui Kementrian Riset dan Pendidikan Tinggi mendorong sivitas akademika untuk melakukan riset dan publikasi. Ini terlihat dari berbagai kebijakan yang dikeluarkan, termasuk Peraturan Menteri Riset, Teknologi dan Pendidikan Tinggi Republik Indonesia nomor 44 Tahun 2015 tentang Standar Standar Nasional Pendidikan Tinggi. Kebijakan ini dimaksudkan salah satunya untuk meningkatkan produktivitas para peneliti dalam penelitian demi kemajuan ilmu pengetahuan, sekaligus mendorong mereka untuk membagi pengetahuan melalui publikasi. Sesuai dengan peraturan yang ada, sivitas akademika, baik dosen maupun mahasiswa, sekarang dituntut untuk melakukan penelitian dengan output diantaranya berupa publikasi, baik publikasi nasional dan internasional. Semakin tinggi jenjang jabatan dosen maka beban penelitian dan publikasi yang harus 
dipenuhi juga semakin tinggi. Demikian juga dengan mahasiswa, semakin tinggi pendidikan yang ditempuh, maka semakin berat juga beban riset dan publikasi mereka. Beban terberat bagi mahasiswa dan dosen dalam bidang publikasi tentu saja berupa publikasi internasional.

Tuntutan publikasi internasional seringkali menjadi tantangan tersendiri bagi sivitas akademika karena sulitnya untuk menembus jurnal yang bereputasi. Naskah yang diterima oleh jurnal bereputasi harus memenuhi standar kualitas yang tinggi. Salah satu standar ini berkaitan dengan prasyarat bahwa naskah tersebut harus bisa memberikan kontribusi bagi pengembangan ilmu pengetahuan. Upaya memberikan kontribusi pada pengembangan keilmuan sendiri hanya bisa dilakukan bila peneliti sudah mengetahui perkembangan terbaru di bidang penelitiannya. Para peneliti dituntut untuk melakukan tinjauan pustaka (literature review), dengan mencari dan mengevaluasi kajian-kajian yang pernah dilakukan di bidang/topik mereka. Mereka dituntut untuk mampu menyampaikan perkembangan terbaru di bidang penelitian mereka secara sistematis Royal literary fund (2018).

Hal ini seringkali menjadi kendala terutama bagi para peneliti ataupun mahasiswa program Doktor yang memiliki target publikasi internasional. Mereka dituntut untuk melakukan tinjauan pustaka secara lebih ekstensif dan mendalam. Literature review merupakan kegiatan yang memakan banyak waktu dan tenaga. Tidak heran bila tahapan ini seringkali dikeluhkan oleh para peneliti. Keluhan lain yang seringkali muncul adalah sulitnya mencari literatur yang relevan dengan bidang kajian mereka.Untuk kajian yang multidisiplin, maka pencarian literatur menjadi jauh lebih rumit. Terkadang kesulitan yang muncul bahkan ada di tahapan awal penelitian, dimana para peneliti merasa bahwa mereka harus mengindari duplikasi penelitian. Mereka juga merasa bahwa untuk mendapatkan ide orisinil untuk penelitian tidaklah mudah.

Menjawab permasalahan ini, maka diperlukan upaya pengembangan keterampilan di kalangan peneliti tentang bagaimana cara menyusun literature review, tidak hanya dari aspek teoritis tentang cakupan dan cara penyusunannya, namun juga alat bantu yang memudahkan para peneliti dalam memahami data tentang literatur yang ada. Keterampilan seperti ini sebenarnya dekat dengan dunia perpustakaan, yakni bibliometri, terutama bibliometric mapping. Paparan ini ditulis sebagai ulasan singkat tentang bibliometric mapping dan kegunaannya dalam membantu literature review, serta peluang pengembangan layanan rujukan di perpustakaan perguruan tinggi berbasis bibliometric mapping

\section{Layanan Bibliometri di Perpustakaan}

Perpustakaan perguruan tinggi dituntut untuk memiliki daya adaptasi yang tinggi. Dinamika yang terjadi di lingkungan perguruan tinggi menjadi dasar perpustakaan untuk selalu berusaha menyesuaikan diri, termasuk dalam pengembangan layanan perpustakaan. Pengembangan layanan baru dilakukan sebagai upaya untuk memberikan manfaat yang lebih luas kepada pemustakanya. Salah satu layanan perpustakaan perguruan tinggi yang seringkali luput dari perhatian adalah layanan bibliometri.

Bibliometri sendiri merupakan cabang ilmu pengetahuan yang berkaitan dengan kajian kuantitatif atas literatur (buku, artikel, dan bentuk komunikasi tertulis lainnya (Heersmink, van den Hoven, Jan van Eck, \& van den Berg, 2010). Kajian kuantatif ini dilakukan dengan melakukan penghitungan matematis atas data bibliografi publikasi. Untuk publikasi berupa artikel jurnal, data ini diantaranya meliputi nama pengarang, afiliasi pengarang, judul artikel, 
judul jurnal, tahun terbit, volume jurnal, nomer terbitan, kata kunci, abstrak, dan daftar pustaka. Semua data ini dianalisis menggunakan teknik penghitungan tertentu, untuk melihat publikasi mana yang paling sering disitir, pengarang mana yang pendapatnya paling sering disitir, kata kunci apa yang paling sering digunakan oleh para pengarang, dll.

Bibliometri dekat sekali dengan bidang perpustakaan. Ada beberapa kajian terkait dengan penyediaan layanan bibliometri di perpustakaan. Corral, Kennan, dan Afzal ( 2013) menyatakan bahwa cakupan layanan bibliografi yang ditawarkan oleh perpustakaan bisa bervariasi, mulai dari pelatihan bibliometri atau bibliometrics literacy; penyusunan citation reports; penghitungan research impact; bantuan penyusunan proposal hibah; evaluasi para kandidat calon staff, calon staff akademik yang akan mendapatkan promosi jabatan; penyusunan trend report bidang keilmuan; ataupun penghitungan $h$-index. Di dunia perpustakaan, layanan bibliometri termasuk sebagai research support services dan yang dikatakan sebagai "higher end researcher support" (Corrall dkk., 2013).

Di Indonesia, biasanya bibliometri dilakukan oleh perpustakaan untuk membantu proses evaluasi layanan perpustakaan, penetapan kebijakan pengembangan koleksi, penetapan kebijakan perbaikan, pembuatan keputusan, alokasi sumber daya serta penyiangan koleksi. Di bidang lebih umum, kajian biblimetri juga bisa dimanfaatkan untuk menganalisa kurikulum dan penilaian kualitas hasil penelitian (Pattah, 2013). Dari sekian bentuk layanan perpustakaan yang berkaitan dengan bibliometri, ada satu layanan yang berpotensi untuk dikembangkan di perpustakaan perguruan tinggi di Indonesia yakni bibliometric mapping. Bibliometric mapping merupakan bagian dari bibliometri yang bertujuan untuk menghasilkan representasi visual atas hubungan-hubungan yang ada diantara unit-unit yang dikaji. Unit kajian bisa berupa dokumen, pengarang, atau kata kunci sedangkan relasi antar unit ini bisa berupa citations, co-citations, co-authorship, atau co-occurrences of keywords (Heersmink dkk., 2010).

Bibliometric mapping dilakukan dengan menggunakan perangkat lunak dan menawarkan kemudahan dalam memahami hasil penghitungan matematis melalui visualisasi data, tanpa mengesampingkan akurasi hasil penghitungan matematis itu sendiri. Untuk topik penelitian yang kompleks, visualisasi data memudahkan orang untuk memperoleh gambaran literatur yang ada secara memadai. Visualisasi data ini juga memungkinkan analisa untuk literatur dengan jumlah yang sangat banyak (Rodrigues, Van Eck, Waltman, \& Jansen, 2014). Visualisasi menggunakan perangkat lunak ini juga user friendly bagi para pengguna yang awam dengan teknik penghitungan bibliometri. Karakteristik bibliometric mapping menjadikan metode ini mendapatkan perhatian cukup luas, tidak hanya di bidang ilmu perpustakaan dan informasi, namun telah digunakan di bidang keilmuan lain. Ia telah banyak digunakan sebagai alat bantu penyusunan tinjauan pustaka, diantaranya oleh Tao (2017), Heersmink, van den Hoven, Jan van Eck, \& van den Berg (2010).

Bibliometric mapping mampu memberikan bekal yang memadai kepada para peneliti untuk mencari literatur yang relevan diantara melimpahnya informasi yang ada sekaligus membantu mengorganisir informasi yang telah didapatkan. Bibliometric mapping bisa memberikan gambaran yang memadai atas penelitian-peineltian yang sudah dilakukan di bidang keilmuan tertentu. Sayangnya pengetahuan dan keterampilan untuk memanfaatkan perangkat lunak seperti ini belum banyak dimiliki oleh para peneliti. Bandara, Furtmueller, Gorbacheva, Miskon, \& Beekhuyzen (2015) mengemukakan bahwa ada beberapa jenis 
perangkat lunak yang bisa dimanfaatkan, mulai dari perangkat lunak untuk analisis data kualitatif (NVivo, ATLAS.ti, dll.), perangkat lunak pengelola dokumen ilmiah atau perangkat lunak pembantu pencatatan (Endnote, Mendeley, Evernote, dll.), citation-analysis tools (CiteSpace, VosViewer, dll.), dan literature-sharing tools (Dropbox, OneNote, OneDrive, d1l.).

Saat ini banyak dikembangkan tool bibliometric mapping yang dapat digunakan untuk membantu penyusunan literature review. Perangkat lunak ini dapat digunakan untuk:

1. Mengidentifikasi pakar di bidang keilmuan tertentu;

Bibliometri bisa digunakan untuk membantu mengidentifikasi siapa saja yang dianggap sebagai pakar untuk suatu bidang keilmuan (Garces, Anthony, Van Blommestein, \& Hillegas-Elting, 2017; Katrenko, 2015). Informasi seperti ini sangat berguna untuk penelusuran literatur yang terkait dengan suatu bidang ilmu, karena publikasi yang dihasilkan oleh seorang pakar biasanya berkisar pada topik tertentu, sesuai dengan bidang kepakaran mereka. Informasi profil pakar akan berguna bagi para peneliti karena ini memudahkan peneliti untuk mengidentifikasi peneliti lain yang bisa diajak untuk berkolaborasi (Forschungszentrum Julich, 2015).

2. Mengetahui key papers suatu subyek;

Hartinah (2002) mengemukakan bahwa kualitas dokumen "biasanya" berbanding lurus dengan jumlah sitiran. Jumlah total sitiran mencerminkan penting tidaknya suatu artikel dengan menghitung berapa kali suatu artikel dikutip sejak dipublikasikan (Zatorski \& Fichna, 2017). Dengan demikian, analisis sitiran juga bisa digunakan untuk mengindentifikasi dokumen inti atau key papers. Bibliometri memudahkan peneliti untuk mengetahui artikel jurnal yang paling relevan dengan bidang kajiannya. Relevansi menjadi hal yang penting karena akan berpengaruh kepada peningkatan kualitas penelitian mereka (Rubio \& Gulo, 2016).

3. Mengidentifikasi jurnal mana saja yang sering disitir;

Bibliometri juga bisa dimanfaatkan untuk mengetahui jurnal mana yang paling sering disitir. Jumlah sitiran jurnal berbanding lurus dengan pengaruh suatu jurnal dalam suatu bidang ilmu. Jurnal yang sering disitir dianggap lebih penting daripada jurnal yang memiliki tingkat sitiran rendah (Zatorski \& Fichna, 2017). Jumlah sitiran ini berkaitan dengan Impact Factor. Para peneliti memiliki preferensi untuk menerbitkan publikasi di jurnal dengan Impact Factor tinggi(Katrenko, 2015). Dengan mengetahui jurnal mana saja yang memiliki Impact Factor tinggi, maka akan lebih mudah bagi peneliti untuk menentukan target jurnal mana saja yang paling tepat menjadi sarana publikasi mereka.

4. Mengekplorasi key terms di bidang keilmuan tertentu;

Suatu bidang ilmu terkadang memiliki cakupan dan kompleksitas tersendiri. Apabila seorang peneliti bisa memperoleh gambaran umum akan bidang penelitiannya tentu ini akan sangat membantu. Gambaran umum ini bisa didapatkan dari topik ataupun konsep kunci berikut relasi yang ada diantara topik atau kata kunci tersebut (Heersmink dkk., 2010). Topik atau konsep kunci suatu bidang dapat diketahui dari frekuensi penggunaannya sebagai kata kunci dalam suatu artikel atau frekuensi penggunannya dalam suatu abstrak. Hal ini akan sangat membantu bagi para peneliti pemula yang akan mendalami suatu bidang. Ini bisa menjadi titik awal untuk mengetahui luas cakupan suatu 
bidang penelitian dengan mengamati semua kata kunci yang digunakan dalam publikasi hasil penelitian.

5. Mengidentifikasi lembaga mana yang paling populer dalam bidang riset tertentu;

Bagi para peneliti informasi tentang lembaga mana saja yang melakukan penelitian untuk suatu topik juga bermanfaat. Penelitian kolaboratif dapat dilakukan dengan menggandeng lembaga-lembaga lain sesuai dengan track record penelitian yang pernah dilakukan lembaga tersebut (Forschungszentrum Julich, 2015).

6. Mengetahui trend penelitian

Bibliometric mapping bisa dimanfaatkan untuk menganalisa trend suatu topik penelitian dari waktu ke waktu (Corrall dkk., 2013). Pengamatan terhadap topik yang paling sering dikaji dalam suatu kurun waktu maka dapat diketahui trend penelitian suatu bidang ilmu pada suatu waktu. Perbandingan juga bisa dilakukan untuk melihat trend penelitian dari waktu ke waktu, sehingga dapat diketahui tahap perkembangan suatu bidang penelitian atau suatu bidang ilmu, tercermin dari konsep/topik yang baru muncul dalam suatu kurun waktu, topik/ konsep yang paling populer (Heersmink dkk., 2010). Pemetaan trend ini sekaligus bisa digunakan untuk mengidentifikasi arah pengembangan penelitian di masa mendatang (Rodrigues dkk., 2014)

\section{Bibliometric Mapping sebagai bentuk Research Support Services di Perpustakaan Perguruan Tinggi}

Saat ini telah banyak dikembangkan software yang dapat membantu para peneliti untuk melakukan analisis bibliometri dengan relatif lebih mudah. Software bibliometric mapping menggunakan data publikasi yang bisa diunduh dari pangkalan data seperti Scopus ataupun Web of Science. Metadata berupa data bibliografis hasil unduhan ini menjadi data mentah dalam melakukan kajian bibliometri. Beberapa software yang bisa digunakan untuk bibliometric mapping (Pradhan, 2016) diantaranya adalah:

\section{VOSviewer}

Software berbasis Java ini gratis dan dapat digunakan untuk mengidentifikasi dan memvisualisasikan jaringan bibliometri, misalnya jaringan jurnal, pengarang, atau publikasi (Gambar 1). Software ini juga memiliki fitur text mining yang bisa digunakan untuk memvisualisasikan frekuensi kemunculan istilah penting dalam suatu dokumen (Gambar 2). Data yang digunakan untuk analisis menggunakan VosViewer bisa menggunakan data bibliografi yang diunduh dari Web of Science, Scopus, PubMed, Dimensions, ataupun file berupa Rich Information Standar (RIS). Software ini dapat diunduh dari http://www.vosviewer.com/download (Jan van Eck \& Waltman, n.d.). 


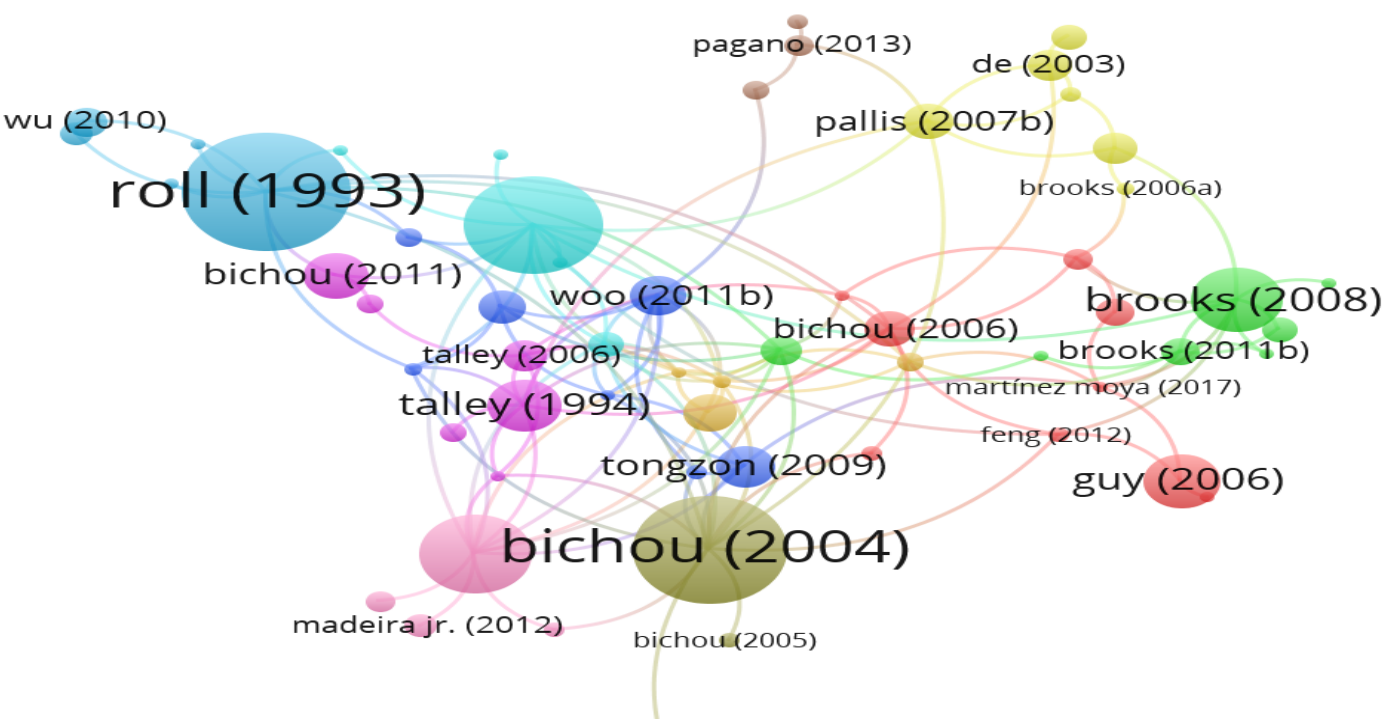

Gambar 1. Contoh hasil identifikasi key papers menggunakan vosviewer untuk subyek "port performance"

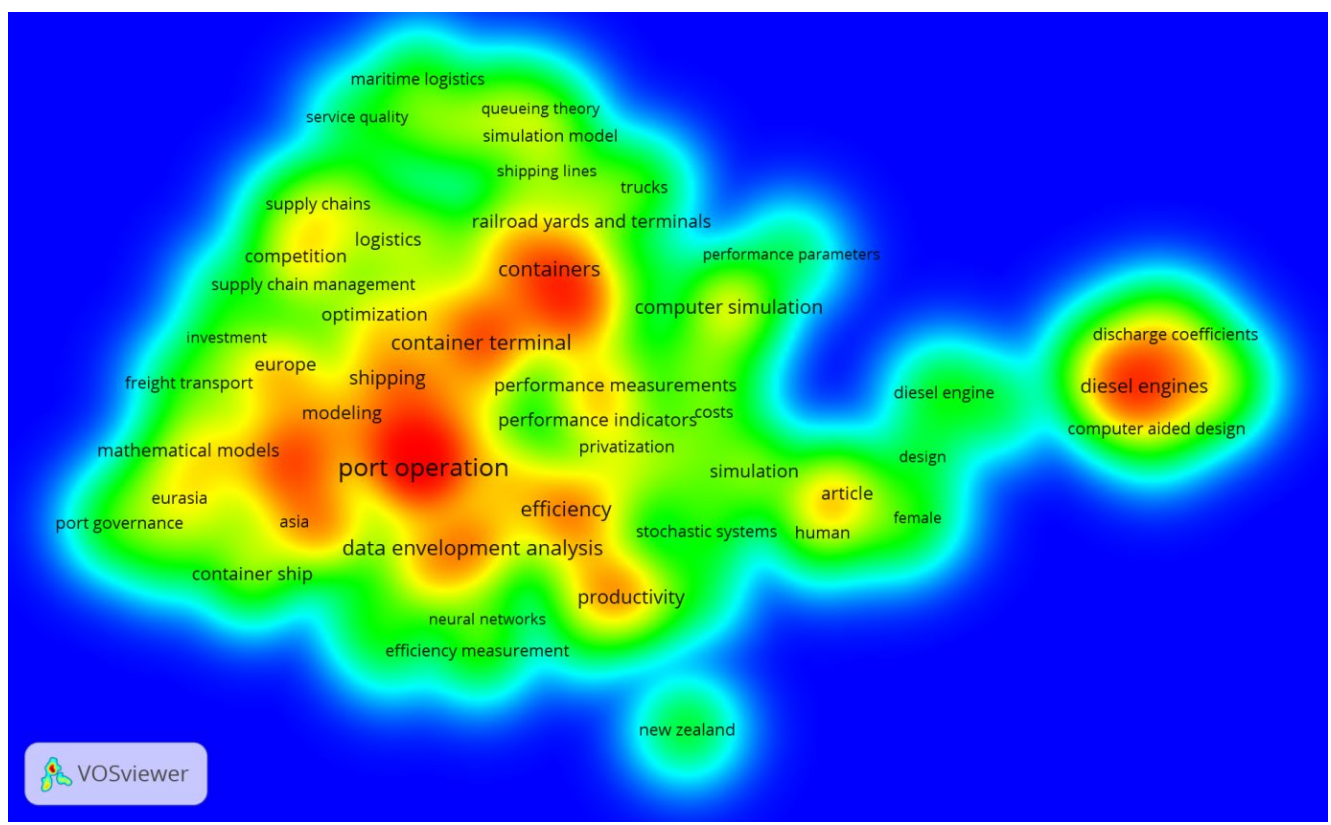

Gambar 2. Contoh hasil identifikasi hot spots menggunakan vosviewer untuk subyek "port performance"

\section{Citespace}

CiteSpace merupakan software gratis berbasis Java. Software ini banyak digunakan untuk menganalisis perkembangan suatu bidang ilmu secara visual, sekaligus melihat trend dan pola-pola dari publikasi ilmiah. Software ini menawarkan beragam fitur yang dapat memudahkan penggunanya dalam memahami perkembangan suatu bidang ilmu berdasarkan urutan waktu, mengidentifikasi topik penelitian yang berkembang paling cepat, bahkan mengelompokkan hasil-hasil penelitian dalam cluster (Gambar 3). Data utama yang digunakan untuk pengolahan melalui CiteSpace adalah Web of Science. CiteSpace juga memberikan fitur tambahan bilamana data yang digunakan berasal dari 
pangkalan data lain, seperti PubMed, arXiv, ADS, dan NSF Award Abstracts. CiteSpace di download dari: http://cluster.ischool.drexel.edu/ cchen/citespace/download/(Chen, 2014).

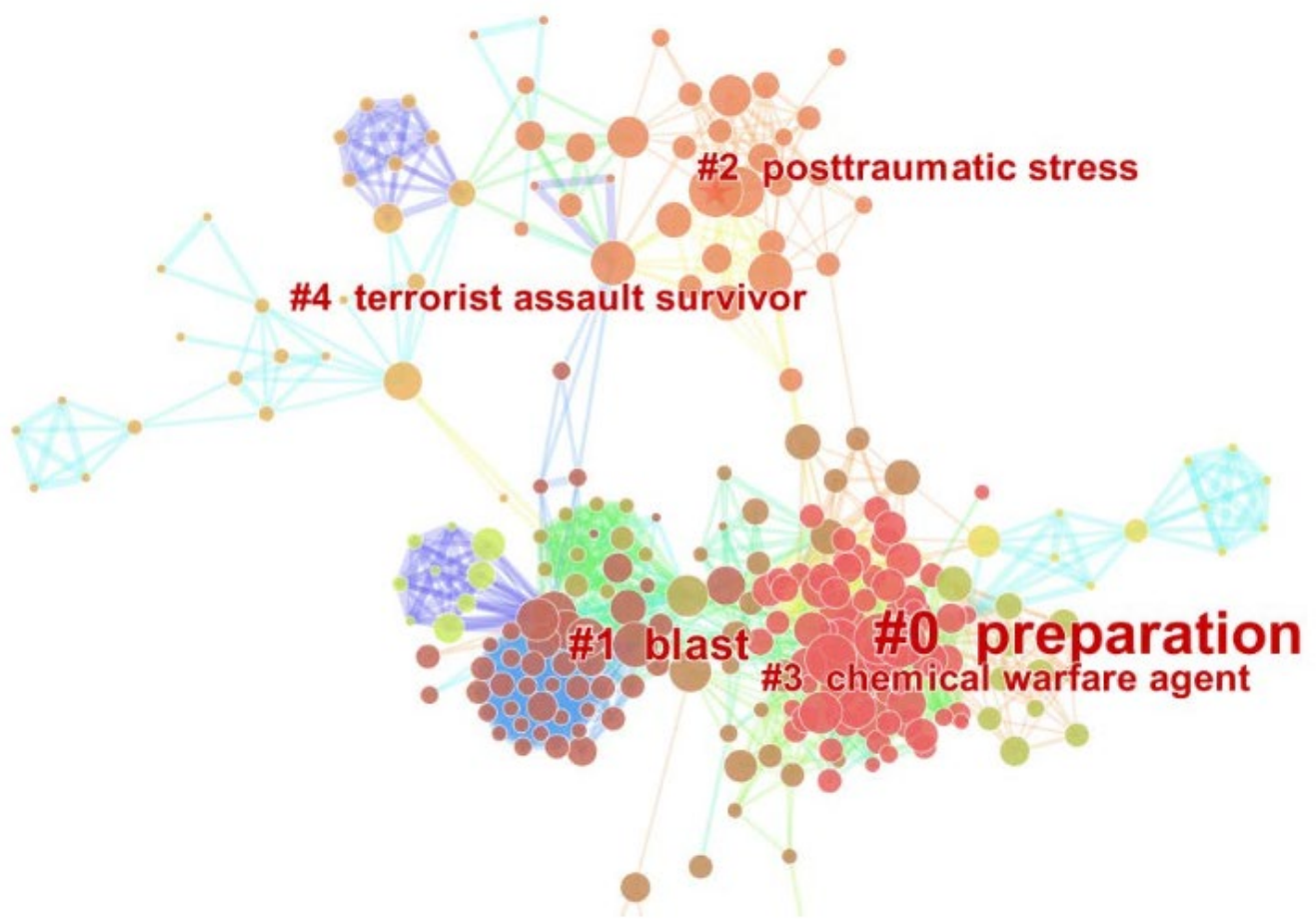

Gambar 3. Clustering untuk pengelompokan tema penelitian melalui CiteSpace(Chen, 2014)

\section{CitNetExplorer}

CitNetExplorer juga merupakan software berbasis Java yang digunakan untuk visualisasi dan analisis jaringan sitiran publikasi ilmiah. Software ini bisa membuat cluster publikasi yang memiliki keterkaitan serta menunjukkan hubungan sitiran langsung dan tidak langsung. CitNetExplorer dapat diunduh di http://www.citnetexplorer.nl/download.

4. Bibliometrix

Biblimetrix merupakan paket pemrograman $\mathrm{R}$ yang dibuat untuk melakukan analisis bibliometri. Bibliometrix bisa di download dari RCRAN Package Repository (https : / /cran. r -project.org/web/packages/bibliometrix/index.html.)

Software bibliometric mapping di atas bisa dikenalkan kepada para peneliti sebagai bagian dari research support services yang diberikan oleh perpustakaan. Pengenalan software seperti ini bisa dikemas sebagai bagian dari pelatihan "Penyusunan Literature Review", dimana para peneliti tidak hanya dibekali dengan teori bagaimana menyusun literature review, namun juga alat bantu yang memudahkan mereka dalam mengeksplorasi suatu bidang ilmu melalui daftar pustaka publikasi.

Bibliometric mapping juga membuka peluang pengembangan layanan perpustakaan perguruan tinggi terutama layanan rujukan. Perpustakaan bisa memberikan bantuan kepada para peneliti dalam melakukan riset, misalnya dalam mencari literatur kunci dalam bidang penelitian mereka, mengidentifikasi topik-topik penelitian yang masih belum banyak digarap 
melalui penelitian-penelitian sebelumnya, mencari jurnal berkualitas yang berpotensi untuk menjadi sasaran media publikasi mereka.

Penelitian yang dilakukan Rethlefsen dkk. (2015) bahkan menunjukkan bahwa keterlibatan pustakawan tidak hanya dalam memberikan layanan pencarian literatur terkait dengan riset yang dilakukan oleh pemustaka. Pustakawan bahkan bersama-sama menyusun systematic literature review sebagai co-author. Penelitian yang dilakukan oleh Rethlefsen dkk ini menunjukkan juga bahwa keterlibatan pustakawan dalam proses systematic literature review berhubungan dengan dengan kualitas yang lebih dalam dalam penerapan strategi pencarian literatur.

Layanan bibliometric mapping memiliki peluang pengembangan yang cukup luas di perpustakaan perguruan tinggi di Indonesia, mengingat jumlah penelitian di Indonesia mengalami peningkatan dari tahun ke tahun, baik penelitian yang dilakukan oleh dosen maupun mahasiswa. Setiap penelitian yang dilakukan tidak bisa lepas dari upaya memetakan penelitian-penelitian terkait yang pernah dilakukan peneliti lain sebelumnya. Pemanfaatan ini kiranya bisa semakin berkembang karena kini semakin banyak software analisis yang bisa dimanfaatkan, dan menjadi bahan perbandingan, misalnya pemrograman $\mathrm{R}$ atau Phyton.

Peluang pemanfaatan software bibliometric mapping ini juga semakin besar dengan adanya wacana Kementrian Riset dan Pendidikan Tinggi yang akan melanggankan Web of Science untuk perguruan tinggi di Indonesia. Hal ini tentu akan memudahkan perguruan tinggi dalam memperoleh data mentah untuk bibliometric mapping. Pemanfaatan data bibliografi sendiri juga merupakan bentuk optimalisasi e-resources yang dilanggan oleh perguruan tinggi, seperti Scopus ataupun Web of Science.

\section{KESIMPULAN}

Perpustakaan bisa mengembangkan layanan yang bisa menjawab kebutuhan sivitas akademika terkait dengan publikasi, terutama terkait dengan literature review. Perpustakaan bisa menawarkan layanan yang berkaitan dengan bibliometric mapping berupa pelatihan penggunaan tools ataupun memberikan layanan penelusuran informasi hasil bibliometric mapping. Layanan bibliometric mapping dapat memberikan manfaat berupa diversifikasi layanan perpustakaan sekaligus juga sebagai bentuk lain dari pemanfaatan database publikasi yang peer-reviewed seperti SCOPUS atau Web of Science. Database SCOPUS yang dilanggan oleh perguruan tinggi dan selama ini hanya digunakan sebagai alat bantu penelusuran informasi, bisa dimanfaatkan sebagai sumber data untuk melakukan analisis bibliometri.

\section{DAFTAR PUSTAKA}

Bandara, W., Furtmueller, E., Gorbacheva, E., Miskon, S., \& Beekhuyzen, J. (2015). Achieving Rigor in Literature Reviews: Insights from Qualitative Data Analysis and

Tool - Support. Communications of the Association for Information System, 37.

Chen, C. (2014). The CiteSpace Manual. Drexel University. doi: 10.1007/s11192-015-1576-8 
Corrall, S., Kennan, M. A., \& Afzal, W. (2013). Bibliometrics and research data management services: Emerging trends in library support for research. Library trends, 61(3), 636674.

Forschungszentrum Julich. (2015). Bibliometrics - What are the Benefits and for Whom? Diambil 2 Agustus 2018, dari http://www.fzjuelich.de/zb/EN/Expertise/bibliometrics/bibliometrics_benefits/bibliometrics_benefits_ node.html

Garces, E., Anthony, J., Van Blommestein, K., \& Hillegas-Elting, J. (2017). Identification of experts using social network analysis (SNA). PICMET 2016 - Portland International Conference on Management of Engineering and Technology: Technology Management For Social Innovation, Proceedings. doi: 10.1109/PICMET.2016.7806578

Hartinah, S. (2002). Analisis sitiran (Citation analysis). Kursus bibliometrika. Jakarta: PDIILIPI.

Heersmink, R., van den Hoven, J., Jan van Eck, N., \& van den Berg, J. (2010). Bibliometric Mapping of Computer and Information Ethics. Leiden. Diambil dari www.cwts.leidenuniv.nl

Jan van Eck, N., \& Waltman, L. (n.d.). Text mining and visualization using VOSviewer. Diambil dari www.vosviewer.com.

Katrenko, S. (2015). Q\&A_ How to use bibliometrics to evaluate interdisciplinary research. Diambil 23 Agustus 2018, dari https://www.elsevier.com/connect/q-and-a-how-to-usebibliometrics-to-evaluate-interdisciplinary-research

Pradhan, P. (2016). Science Mapping and Visualization Tools used in Bibliometric \& Scientometric Studies: An Overview. Inflibnet, 23(4), 19-33.

Rethlefsen, M. L., Farrell, A. M., Osterhaus, L. C., \& Brigham, T. J. (2015). Librarian coauthors correlated with higher quality reported search strategies in general internal medicine systematic reviews. Journal of Clinical Epidemiology, 68, 617-626. doi: 10.1016/j.jclinepi.2014.11.025

Rodrigues, S. P., Van Eck, N. J., Waltman, L., \& Jansen, F. W. (2014). Mapping patient safety: a large-scale literature review using bibliometric visualisation techniques. $B M J$ Open, 4, 1-8. doi: 10.1136/

Royal literary fund. (2018). What is a literature review. Diambil 12 September 2018, dari https://www.rlf.org.uk/resources/what-is-a-literature-review/

Rubio, T. R. P. M., \& Gulo, C. A. S. J. (2016). Enhancing Academic Literature Review through Relevance Recommendation: using bibliometric and text-based features for classification. 70-75.

Tao, Y., \& Wu, W.-N. (2017). Supplementing the Review of Business Simulation Games via Bibliometrics Analysis.

Zatorski, H., \& Fichna, J. (2017). Young GI angle: The role of bibliometrics in scientist's career development. United European Gastroentorology Journal, 5(8), 1151-1152. doi: $10.1177 / 2050640617744497$ 